\title{
INVESTIGATION OF THE CINNAMON INFLUENCE ON THE WHEAT BREAD QUALITY ENRICHED WITH FLAX SEEDS \\ OIL MEAL
}

\author{
Olena Bilyk \\ Department of Technology of bakery and confectionery products \\ National University of food technologies \\ 68 Volodymyrska str., Kyiv, Ukraine, 01601 \\ bilyklena@gmail.com \\ Yulia Bondarenko \\ Department of Technology of bakery and confectionery products \\ National University of food technologies \\ 68 Volodymyrska str., Kyiv, Ukraine, 01601 \\ bjuly@ukr.net \\ Anna Hryshchenko \\ Department of Technology of bakery and confectionery products \\ National University of food technologies \\ 68 Volodymyrska str., Kyiv, Ukraine, 01601 \\ grischenko_anna@ukr.net \\ Vira Drobot \\ Department of Bakery and Confectionary Goods Technology \\ National University of Food Technologies \\ 68 Volodymyrska str., Kyiv, Ukraine, 01601 \\ v.i.drobot@ukr.net \\ Volodymyr Kovbasa \\ Department of Bakery and Confectionary Goods Technology \\ National University of Food Technologies \\ 68 Volodymyrska str., Kyiv, Ukraine, 01601 \\ kovbasavm19091@ukr.net \\ Vitaliy Shutyuk \\ Department of Technology of Preservation \\ National University of Food Technologies \\ 68 Volodymyrska str., Kyiv, Ukraine, 01601 \\ schutyuk@i.ua
}

\footnotetext{
Abstract

The materials of the article are studies that are conducted with the aim of expanding the use of non-traditional raw materials for functional purposes in the technology of bakery products. Research is conducted to determine the effect of spiciness cinnamon on the quality of semi-finished products and finished bakery products from wheat flour enriched with flax seeds oil meal.

To improve the quality of wheat bread, enriched with flax seeds oil meal, and expand the assortment of bakery products with health properties, the authors propose to use spice cinnamon in the formula of wheat bread in an amount of up to $2 \%$ of the weight of flour. The taste and aroma of these products is characteristic of wheat bread with a pleasant cinnamon flavor. Dosage of cinnamon to $4 \%$ of the flour mass also provides good consumer characteristics of products, however, more pronounced flavor and flavor of cinnamon can limit the circle of consumers of such products. The use of $6 \%$ of cinnamon in the recipe of products leads to a significant deterioration in the volume of products and provides them with too intense flavor. Determination of the content of bisulphite-binding substances in the crumb and crust of products is confirmed by improvements in the fragrance of products with the addition of cinnamon.

It has been established that the cinnamon in dough leads to an increase in the elastic properties of gluten, and the more, the more it is added. Along with this, it is noted that cinnamon leads to a decrease in the fermentation intensity of the dough. This is
} 
probably due to the active antibacterial properties of cinnamon, which suppress the yeast fermentation activity. These factors and cause the deterioration of the volume of finished products in the case of dosing cinnamon in an amount of $4 \%$ or more.

It has been proved that on the indicators of crumbling and deformation of the crumb, products with added cinnamon retain their freshness similarly to the control one. However, it is noted that the introduction of cinnamon reduces the amount of mold of microflora in products.

Keywords: wheat bread, cinnamon, hardening, gluten, molding.

\section{Introduction}

Modern people consume a lot of refined foods. The component of the daily diet of a person is bread. Therefore, enriching it with dietary fiber and giving it the properties of a health product is topical.

To enhance the health properties of bakery products, it is advisable to introduce flax seeds and products of its processing into their recipes $[1,2,3]$. In particular, flax seeds oil meal valuable in chemical composition raw materials. It is a by-product of flax oil production by the method of "cold" pressing [4]. Taking into account that flax seeds oil meal has 11 times more than wheat flour, the content of dietary fiber, both soluble and soluble, was included by scientists [5] into the formula of wheat bread from the first grade flour. The dough baking shows that with the aim of maximally enriching the bread with the oil meal components, taking into account the technological aspects of its use, it is advisable to add $7.5 \%$ of the flax seeds oil meal into the dough. According to the organoleptic indicators, such products have flax off-flavor and flavor [5]. Spices are used to improve the taste and flavor of products in the bakery. Cinnamon is one of the most common spices in bakery. However, cinnamon is used primarily for finishing bakery products, and not as dough ingredient. Therefore, there is insufficient information in the literature about its optimal dosage as a prescription ingredient and the influence on the course of the technological process and the quality of the products.

Given the antibacterial properties of cinnamon, Spanish scientists [6] developed a new type of packaging for bakery products made of paper impregnated with brown oil. Such package was called "active", because it inhibits the growth of mold of microflora in products wrapped up in them by $96 \%$. This property of cinnamon will help prevent molding of finished products, in the recipe of which it is introduced.

Along with a fraction of flax seeds in the formula of wheat bread, cinnamon will also have a positive effect on human health, because it: prevents the formation of blood clots due to the content of the valuable aldehyde of brown matter; helps stabilize blood sugar and increase insulin sensitivity; strengthens the cardiovascular system; thanks to its antibacterial, antiviral and anti-inflammatory properties, it helps to treat external and internal infections; helps to reduce the increased acidity in the stomach [7].

The aim of research is determination of the cinnamon influence on the course of the technological process, the quality of the finished products and the preservation of freshness of bakery products enriched with flax seeds oil meal. The given researches will allow to expand assortment of nonconventional raw materials in technology of bakery products.

To achieve this aim, the following tasks are formulated:

- to establish the optimum dosage of cinnamon for obtaining products of traditional quality;

- to investigate the cinnamon effect on molding of products.

\section{Materials and Methods}

Spice cinnamon is used in the form of powder and flax seeds oil meal from the production of «Zhitomirbioproduct», produced by the method of "cold" pressing.

To assess the quality of bread with the addition of cinnamon and to determine its optimal dosage, a laboratory baking dough is carried out. During the study, dough made from first grade 
flour was prepared with cinnamon in the amount of $2 ; 4$ and $6 \%$ to the mass of flour. The control sample has the following formula: wheat flour of the first grade $-100 \mathrm{~g}$, yeast $-3 \%$, salt $-1.5 \%$, flax seed oil meal $-7.5 \%$. Humidity of all dough samples is $42 \%$. The dough is cooked in a freeform way. The duration of fermentation of all dough samples is 170 minutes. Before mixing the dough, the cinnamon and the flax seed meal are mixed with wheat flour. The dough is kneaded in a two-speed kneader. The dough is handled manually, the dough pieces are stored in a thermostat at a temperature of $(38 \pm 2){ }^{\circ} \mathrm{C}$ and relative humidity $(78 \pm 2) \%$ until ready. The products are baked in a cabinet oven at a temperature of $220 \ldots 240{ }^{\circ} \mathrm{C}$.

The bread quality is evaluated according to physical and chemical (specific volume, acidity) and organoleptic characteristics (appearance, crustal surface condition, porosity structure, taste, flavor) [8]. The organoleptic evaluation is carried out by comparing the quality of the products obtained with standard indices. The assessment is attended by five tasters-experts in the bakery industry. Each indicator is assessed on a five-point scale. Each score characterizes a certain level of quality: "5" - excellent, "4" - good, " 3 " - satisfactory, "2" - not satisfactory, "1" - not satisfactory. The conclusion is made based on the processing of expert assessments.

The content of aromatics in finished products is evaluated by the number of bisulphite-binding compounds [9]. This method is based on the ability to bind aldehydes and certain ketones with sodium bisulphite to form adducts. The method consists in preliminary removal of unreacted bisulphite with iodine followed by destruction of the sodium bicarbonate adduct and bisulphite processing, which is discharged, equivalent to the content of carbonyl compounds.

The hardening degree of bread is also investigated for crumbling of crumb. Crumbling is estimated by crumb formation due to friction of two pieces of bread crumbs weighing $5 \mathrm{~g}$ cut in the form of a parallelepiped by shaking for 5 minutes on a shaker IKA HS 501 digital (IKA®-Werke $\mathrm{GmbH} \& \mathrm{Co}$. KG (Germany)). Crumbling is expressed as the ratio of the mass of crumb to the weight of the bread sample in percent [8].

Control of microbiological contamination by mold is determined by the number of colony forming units in $1 \mathrm{~g}$ of product [10].

The results of the experimental studies are processed using methods for calculating the statistical validity of the measurement results. Approximations of the empirical data are carried out using MSExcel spreadsheets (2010 version).

\section{Results}

Analysis of the results (Table 1) of laboratory baking dough identifies that in the case of the addition of cinnamon, the initial acidity of the dough does not change, but the final acidity of the semi-finished products decreases according to the increase in dosage. The duration of proofing of dough billets with cinnamon is increased, especially at a dosage of $6 \%$ for 18 minutes compared to the control.

The decrease in acid storage and the increase in the duration of proofing the dough pieces are probably due to deterioration in the fermentation intensity of the dough. Thus, it is found that in the case of the cinnamon addition, a decrease in the amount of carbon dioxide released is observed. In this case, in the case of dosing, $2 \%$ of the flour mass decreases by $1.5 \%$, and 4 and $6 \%$ by weight of the flour by $-12.5 \ldots 29 \%$ compared to the control. This, probably, is due to the deterioration of yeast fermentation activity, which is due to the antibacterial properties of cinnamon.

In addition, it is found that in the case of dosing cinnamon 4 and $6 \%$ of the flour mass, the gas-retaining capacity of the semi-finished products is reduced. Probably this is due not only to the less intense fermentation of these semi-finished products, but also to the strengthening of gluten dough under the action of constituents of cinnamon. Assumptions for strengthening gluten are confirmed by the dough running.

The study of the cinnamon influence on the quantity and quality of gluten shows (Table 2) that the cinnamon addition does not affect the amount of gluten in the dough, but strengthens it, as evidenced by the results of extensibility and elasticity. In the case of dosing 4 and $6 \%$ of the weight of flour, gluten is significantly strengthened, which in turn worsens its elasticity. 
Table 1

Indicators of the technological process and product quality $n=3, p \leq 0.95$

\begin{tabular}{|c|c|c|c|c|}
\hline \multirow{2}{*}{ Indicator } & \multirow{2}{*}{ Control } & \multicolumn{3}{|c|}{ Cinnamon, \% by flour weight } \\
\hline & & 2 & 4 & 6 \\
\hline \multicolumn{5}{|c|}{ Dough } \\
\hline Dough humidity, \% & 41.9 & 41.8 & 41.7 & 42.0 \\
\hline Acidity, degree & & & & \\
\hline primary & 2.4 & 2.4 & 2.4 & 2.4 \\
\hline ultimate & 3.2 & 3.1 & 2.8 & 2.6 \\
\hline Fermentation duration, min & \multicolumn{4}{|c|}{170} \\
\hline Proofing duration, min & 50 & 52 & 57 & 68 \\
\hline $\begin{array}{l}\text { The amount of carbon dioxide re- } \\
\text { leased during the fermentation of the } \\
\text { dough and the proofing of the dough } \\
\text { billets, } \mathrm{cm}^{3} / 100 \mathrm{~g} \text { of dough }\end{array}$ & 985 & 975 & 860 & 700 \\
\hline Dough ball running, $\mathrm{mm}$ & 75 & 73 & 68 & 61 \\
\hline $\begin{array}{l}\text { Gas-retaining capacity of the dough } \\
\text { for } 4 \text { hours of fermentation, } \mathrm{cm}^{3} / \mathrm{g}\end{array}$ & 2.65 & 2.68 & 2.54 & 2.31 \\
\hline \multicolumn{5}{|c|}{ Bread } \\
\hline $\begin{array}{l}\text { Surface condition } \\
\text { crumb color } \\
\text { crumb elasticity }\end{array}$ & \multicolumn{4}{|c|}{$\begin{array}{l}\text { Smooth without cracks and blasting } \\
\text { golden brown tinge } \\
\text { Elastic }\end{array}$} \\
\hline Flavor and aroma & $\begin{array}{l}\text { Characteristic of } \\
\text { wheat bread with a } \\
\text { flax seed fraction }\end{array}$ & $\begin{array}{r}\text { Characteristic } \\
\text { ant }\end{array}$ & $\begin{array}{l}\text { d with a pleas- } \\
\text { vor }\end{array}$ & $\begin{array}{l}\text { Characteristic of } \\
\text { wheat bread with } \\
\text { intense cinnamon } \\
\text { flavor }\end{array}$ \\
\hline \multicolumn{5}{|l|}{$\begin{array}{l}\text { The content of bisulphite-binding } \\
\text { substances, } \mathrm{mg} \text {-eq } / 100 \mathrm{~g} \text { of bread } \\
\text { after } 4 \text { hours of storage }\end{array}$} \\
\hline - in crust & 12.5 & 17.9 & 18.7 & 19.8 \\
\hline - into crumb & 7.1 & 9.1 & 9.7 & 11.1 \\
\hline Specific volume, $\mathrm{cm}^{3} / \mathrm{g}$ & 2.73 & 2.78 & 2.68 & 2.43 \\
\hline Porosity, \% & 72 & 72 & 70 & 69 \\
\hline Acidity, degree & 2.8 & 2.7 & 2.5 & 2.2 \\
\hline H/D formability & 0.44 & 0.46 & 0.47 & 0.40 \\
\hline $\begin{array}{l}\text { Total deformation of the crumb, } \\
\text { units after } 4: 00 \text { : }\end{array}$ & 77 & 73 & 68 & 63 \\
\hline in 48 hours: & 43 & 39 & 36 & 34 \\
\hline Freshness preservation degree, $\%$ & 52 & 53 & 53 & 54 \\
\hline \multicolumn{5}{|l|}{ Crumbling, \% } \\
\hline In 4 hours & 5.8 & 5.8 & 5.6 & 5.6 \\
\hline In 48 hours & 9.6 & 9.5 & 9.3 & 9.1 \\
\hline $\begin{array}{l}\text { Mold fungi, CFU per } 1 \mathrm{~g} \text {, not more } \\
\text { than }\end{array}$ & $1.0 \cdot 10^{2}$ & $1.0 \cdot 10^{2}$ & $1.0 \cdot 10^{2}$ & $1.0 \cdot 10^{2}$ \\
\hline
\end{tabular}

Table 2

The quantity and quality of gluten in the dough $n=3, p \leq 0.95$

\begin{tabular}{ccccc}
\hline Indicator & Control & \multicolumn{3}{c}{ Cinnamon, \% by flour weight } \\
\cline { 3 - 5 } & 28,7 & $\mathbf{2 , 0}$ & $\mathbf{4 , 0}$ & $\mathbf{6 , 0}$ \\
\hline Amount, \% & 14 & 28,5 & 28,4 & 28,6 \\
$\begin{array}{c}\text { Extensibility, cm } \\
\begin{array}{c}\text { Resilience, Index Defort } \\
\text { mation Gluten unit }\end{array}\end{array}$ & 70 & 12 & 10 & 8 \\
Elasticity & good & good & satisfactory & 55 \\
& & & satisfactory
\end{tabular}


The change in the quality of semi-finished products due to the addition of cinnamon influences the formation of specific volume, form stability and porosity of finished products.

It is found that the specific volume of finished products with cinnamon application in the case of dosing of $2 \%$ to the weight of flour is somewhat improved, probably due to the improvement of the elastic properties of the dough, and in case of dosing 4 and $6 \%$, probably due to significant gluten strengthening and deterioration of yeast fermentation activity .

The form-stability of the products for dosing $2 \%$ and $4 \%$ of cinnamon is better than in the control, however, high gluten elasticity and low intensity of fermentation of the dough by $6 \%$ cinnamon dosing caused a significant reduction in the shape stability of the products.

The use of cinnamon in the formula of wheat bread in an amount of up to $2 \%$ of the mass of flour forms the taste and aroma of the products is inherent in wheat bread with a pleasant cinnamon flavor. Dosage of cinnamon to $4 \%$ of the flour mass also provides good consumer characteristics of products, however, more pronounced off-flavor and flavor of cinnamon can limit the circle of consumers of such products. The use of $6 \%$ of cinnamon in the recipe of products leads to a significant deterioration in the volume of products and provides them with too intense flavor. Determination of the content of bisulphite-binding substances in the crumb and crust of products confirmed improvements in the fragrance of products with the cinnamon addition.

The analysis of the products during storage for the indicators of crumbling and deformation of the crumb of the product with the addition of cinnamon retain freshness similar to the control one.

\section{Conclusions}

The research results show that in order to improve the quality of wheat bread enriched with flax seeds oil meal, and to expand the assortment of bakery products with health properties, it is recommended to use spicy cinnamon in the formula of wheat bread in an amount of up to $2 \%$ of the flour mass. Dosage of cinnamon to $4 \%$ of the flour mass also provides good consumer characteristics of products, however, more pronounced off-flavor and flavor of cinnamon can limit the circle of consumers of such products. Dosage of $6 \%$ of cinnamon leads to a significant deterioration in the volume of products and provides them with too intense flavor. Determination of the content of bisulfite-binding substances in the crumb and crust of products confirms improvements in the fragrance of products with the cinnamon addition.

It has been established that the cinnamon dosage in dough leads to an increase in the elastic properties of gluten, and the more, the more it is added. Along with this, it is noted that cinnamon leads to a decrease in the fermentation intensity of the dough. These factors and cause the deterioration of the volume of finished products in the case of dosing cinnamon in an amount of $4 \%$ or more.

It is proved that the use of cinnamon prolongs the freshness duration of bakery products enriched with flax oil meal.

The obtained results allow expanding the assortment of non-traditional raw materials in the technology of bakery products, namely spices of cinnamon, which plays the role of a structure-forming agent. Further research will concern the effect of cinnamon on the structural and mechanical properties of the dough, both from wheat flour varieties and mixtures of rye and wheat.

\section{References}

[1] Melnichenko, O. V., Lebedenko, T. Ye., Krusir, H. V., Rusieva, Ya. P. (2008). Rozrobka tekhnolohii pshenychnoho khliba z pidvyshchenoiu kharchovoiu tsinnistiu. Hranenie i pererabotka zerna, 12, 75-78.

[2] Kireeva, M. S. (2012). Perspektivnoe ispol'zovanie semeni l'na v specializirovannom pitanii. Materialy mezhdunarodnoy nauchno-prakticheskogo seminara «Rol' l'na v uluchshenii sredy obitaniya i aktivnogo dolgoletiya cheloveka. Tver', 181-185.

[3] Yurchenko, O. O. (2011). Nasinnia lonu ta produkty pererobky na yoho osnovi yak pryrodni antyoksydanty. Hranenie i pererabotka zerna, 4, 66-67.

[4] Drobot, V. I., Izhevska, O. P., Bondarenko, Yu. V. (2015). Doslidzhennia vplyvu shrotu lonu na yakist khliba. Zernovi produkty i kombikormy, 1 (57), 42-45. doi: 10.15673/2313-478x.57/2015.39738

[5] Drobot, V. I., Izhevskaya, O. P., Bondarenko, Yu. V. (2017). Shrot semyan l'na - istochnik ingredientov dlya pridaniya hlebu ozdorovitel'nyh svoystv. Pekar' \& Konditer, 5 (11), 41-43. 
[6] Rodríguez, A., Nerín, C., Batlle, R. (2008). New Cinnamon-Based Active Paper Packaging againstRhizopusstoloniferFood Spoilage. Journal of Agricultural and Food Chemistry, 56 (15), 6364-6369. doi: $10.1021 /$ jf800699q

[7] Ganushchenko, O. F. (2009). L'nosemya, produkty ego pererabotki i ih prakticheskaya cennost'. Belorusskoe sel'skoe hazyaystvo, 10, 18.

[8] Lebedenko, T. Ie., Pshenyshniuk, H. F., Sokolova, N. Iu. (2014). Tekhnolohiya khlibopekarskoho vyrobnytstva. Praktykum: navch. Posibnyk. Odesa: «Osvita Ukrainy», 392.

[9] Drobot, V. I. (Ed.) (2015). Tekhnokhimichnyi kontrol syrovyny ta khlibobulochnykh i makaronnykh vyrobiv. Kyiv: NUKhT, 902.

[10] Hrehirchak, N. M. (2009). Mikrobiolohiya kharchovykh vyrobnytstv. Laboratornyi praktykum. Kyiv: NUKhT.

\title{
DEVELOPMENT OF TECHNOLOGICAL DECISIONS ON PRODUCTION OF CAPSULATED PRODUCTS BASED ON DAIRY RAW MATERIALS
}

\author{
Nataliya Grynchenko \\ Department of Meat Processing Technologies \\ Kharkiv State University of Food Technologies and Trade \\ 333 Klochkivska str., Kharkiv, Ukraine, 61051 \\ tatagrin1201@gmail.com \\ Pavlo Pyvovarov \\ Department of Food Technology \\ Kharkiv State University of Food Technologies and Trade \\ 333 Klochkivska str., Kharkiv, Ukraine, 61051 \\ pcub@ukr.net
}

\begin{abstract}
Capsulated products is a segment of the food industry with high rates of development in directions of creating analogues of black and red caviar, oil-fatty capsulated products, capsulated sauces, capsules, based on milk raw materials and also getting capsules with probiotic properties. It is determined, that milk is used as a "passive" recipe component (excretion of separate components, matrix for bifidobacteria) with the additional use of $\mathrm{CaCI} 2$ for realizing encapsulation processes. It determines the aim of the studies - development of new technological principles and approaches to the technologies of processing dairy raw materials taking into account their chemical and technological potentials. At that there is offered to use the potential of lactocalcium of whey for realizing the encapsulation process that gives a possibility to exclude auxiliary substances, especially CaCI2 from the technological process. There was developed the innovative plan of products, within which there is presented the conception of new products, their competitive advantages, determined the segment of users and consumers. There was elaborated the technological process of producing capsulated products, based on dairy raw materials involving secondary milk products, especially whey. It is noted, that the necessity of introducing whey is conditioned by its properties to be a donor of ionic calcium that is a condition of encapsulation process realization. There were studied the ways of the development of the technology of capsulated products, so a possibility of getting both fermented products and pasteurized ones appears at the expanse of thermostable properties of the coat of capsulated semi-products. It is determined, that the offered technological decisions allow to define directions of milk processing, to create products with high food properties and to offer products of new commodity forms - soft capsulated snack cheeses, soft capsulated dessert cheeses. It is proved, that the technological process of producing capsulated products taking into account consuming advantages provides the effectiveness of business functioning in the link "milk industry-restaurant industry-consumer".
\end{abstract}

Keywords: capsulated products, encapsulant, dairy raw materials, lactocalcium, soft cheese. 